\title{
Flora da Bahia: Limnocharitaceae
}

\author{
Danilo José Lima de Sousa ${ }^{1 *}$, Ana Maria Giulietti ${ }^{1,2,3 a}$ \& Reyjane Patrícia de Oliveira ${ }^{1, b}$ \\ ${ }^{1}$ Programa de Pós-graduação em Botânica, Departamento de Ciências Biológicas, Universidade Estadual de Feira \\ de Santana, Feira de Santana, Bahia, Brasil. \\ ${ }^{2}$ Herbarium, Royal Botanic Gardens, Kew, Reino Unido. \\ ${ }^{3}$ Instituto Tecnológico Vale, Belém, Pará, Brasil.
}

\begin{abstract}
Resumo - É apresentado o levantamento florístico de Limnocharitaceae do estado da Bahia, Brasil. Foram reconhecidas três espécies do gênero Hydrocleys (H. martii, H. modesta e H. nymphoides) e duas do gênero Limnocharis (L. flava e L. Laforestii). O tratamento inclui descrição dos táxons, chaves de identificação, além de mapas de distribuição, ilustrações e comentários para as espécies.

Palavras-chave adicionais: macrófitas aquáticas, Nordeste do Brasil, taxonomia.
\end{abstract}

\begin{abstract}
Flora of Bahia: Limnocharitaceae) - The floristic survey of the Limnocharitaceae from the state of Bahia, Brazil, is presented. Three species in the genus Hydrocleys (H. martii, H. modesta and H. nymphoides) and two in the genus Limnocharis (L. flava and L. laforestii) were recognized. The treatment includes taxa descriptions and keys for identification, illustrations, distribution maps and comments for species.
\end{abstract}

Additional key words: aquatic macrophytes, Brazilian Northeast, taxonomy.

\section{LIMNOCHARITACEAE}

Ervas perenes, fixas no substrato, com folhas e inflorescências flutuantes ou emergentes, dulcícolas, rizomatosas, latescentes, glabras. Raízes fibrosas, poucas a numerosas, não septadas. Estolões presentes ou não. Folhas flutuantes ou emersas, alternas, espiraladas, basais, longo-pecioladas; pecíolos inflados ou não, cilíndricos ou triangulares; lâminas lanceoladas a circulares, ápice agudo a arredondado, raramente emarginado-mucronado, base arredondada a atenuada ou cordada; venação reticulada, nervuras primárias paralelas, curvinérveas; margem inteira. Inflorescências umbeliformes, terminais, com proliferações vegetativas ou não; escapo ereto ou flutuante; invólucro com poucas a várias brácteas lanceoladas a ovais, membranosas, livres. Flores trímeras, actinomorfas, bissexuadas, longopediceladas; pedicelos triangulares ou cilíndricos, inflados ou não, alados ou não; cálice dialissépalo, sépalas verdes a vináceas, coriáceas, persistentes, com nervura central evidente ou não; corola dialipétala, pétalas amarelas a creme, delicadas, decíduas; estames 6 a vários, em 1 a várias séries, livres, filetes lineares a lanceolados, achatados, anteras 2-tecas, oblongas a sagitadas ou lanceoladas, basifixas, rimosas; estaminódios ausentes ou numerosos, em 1 a várias séries externas aos estames, lineares, ápice bifurcado ou arredondado; carpelos 3 a vários, livres ou dorsalmente conatos, estilete curto ou ausente, estigma capitado, placentação laminar, óvulos numerosos. Fruto folículo, glabro, deiscência ao longo da margem

\footnotetext{
*Autor para correspondência: danilojls@yahoo.com.br; aanagiulietti@hotmail.com; brpatricia@uefs.br;

Editor responsável: Abel Augusto Conceição

Submetido: 25 jun. 2015; aceito 20 nov. 2015

Publicação eletrônica: 2 dez. 2015; versão final: 7 dez. 2015
}

interna. Sementes numerosas, sem endosperma, encurvadas, costadas ou não, glabras ou pubescentes, tricomas glandulares.

Limnocharitaceae possui distribuição pantropical e inclui três gêneros. Limnocharis Humb. \& Bonpl. e Hydrocleys Rich. ocorrem do México até a Argentina, incluindo as ilhas do Caribe, enquanto Butomopsis Kunth ocorre nos trópicos da África, Ásia e Austrália (Haynes \& Holm-Nielsen 1992). Foram citadas sete espécies dos gêneros Limnocharis e Hydrocleys nas Limnocharitaceae do Brasil, das quais quatro ocorrem na Bahia (Sakuragui et al. 2010). Mais recentemente, Matias et al. (2015) confirmaram a ocorrência desses gêneros no país, porém considerando-os na família Alismataceae.

Limnocharitaceae foi proposta como família por Takhtajan (1954), mas uma descrição em latim e o gênero-tipo da família só apareceram em Cronquist (1981), que a incluiu juntamente com Butomaceae e Alismataceae na ordem Alismatales. A posição de Limnocharitaceae e Alismataceae como famílias distintas ainda está em debate. Alguns autores (e.g., Haynes \& Holm-Nielsen 1992; Pansarin \& Amaral 2002; APG II 2003; Petersen et al. 2006; Heywood et al. 2007; Li \& Zhou 2009; Lehtonen 2009; Sakuragui et al. 2010; Pansarin 2015) aceitaram o posicionamento de Limnocharitaceae como família distinta de Alismataceae, enquanto outros (e.g., Les et al. 1997; Chen et al. 2004; Lehtonen \& Myllys 2008) incluíram os três gêneros de Limnocharitaceae em Alismataceae, indicando os grãos de pólen pantoporados e espinescentes como sinapomorfia morfológica da família (Furness \& Banks 2010).

O APG III (2009) incluiu Limnocharitaceae na sinonímia de Alismataceae, classificação adotada na Lista de Espécies da Flora do Brasil (Matias et al. 2015). No entanto, Cuenca et al. $(2010,2012)$ e 
Petersen et al. (2015) destacaram que Alismataceae s.s. e Limnocharitaceae apresentam alto suporte como clados distintos em algumas análises, o que favoreceria a manutenção de Alismataceae como família distinta de Limnocharitaceae. Assim, os autores chamaram a atenção para a necessidade de novas análises visando o esclarescimento dessa relação.

Considerando a incerteza em relação à separação ou não de Limnocharitaceae e Alismataceae, essas duas famílias estão sendo consideradas separadamente na Flora da Bahia, especialmente por serem facilmente reconhecidas, tanto em campo como no laboratório. Limnocharitaceae possui flores amarelas, carpelos pluriovulados com placentação laminar e frutos do tipo folículo, enquanto Alismataceae s.s. apresenta flores brancas, carpelos uniovulados com placentação basal e frutos do tipo aquênio.

\section{Chave para os gêneros}

1. Ervas fixas; folhas flutuantes com pedicelo cilíndrico, não inflado, não alado; carpelos 3-8, livres; estilete presente; frutos cônicos; sementes indumentadas, com tricomas glandulares, sem costelas transversais ....................... 1. Hydrocleys

1'. Ervas emergentes; folhas emersas, com pedicelo triangular, inflado, frequentemente alado; carpelos 12-19, conatos dorsalmente; estilete ausente; frutos semicirculares; sementes glabras, com costelas transversais

2. Limnocharis

\section{Hydrocleys Rich.}

Ervas fixas, geralmente com estolões. Folhas flutuantes; pecíolo não inflado, cilíndrico; lâmina lanceolada a circular, ápice obtuso a arredondado, frequentemente mucronado, base cordada a arredondada. Inflorescências frequentemente com proliferações vegetativas, com poucas a várias flores; escapo flutuante, septado; brácteas elípticas a largamente lanceoladas. Flores com pedicelo cilíndrico, não inflado, não alado; sépalas verdes a vináceas, lanceoladas, ápice cuculado, nervura central evidente ou não; pétalas amarelas a creme, obovais; estames 6 a vários, filetes lineares a lanceolados, anteras oblongas a sagitadas; estaminódios ausentes ou numerosos, em 1 a várias séries, ápice frequentemente bifurcado; gineceu 3-8-carpelar, carpelos cônicos, estilete curto. Frutos cônicos. Sementes sem costelas transversais, esparsas ou densamente pubescentes.

O gênero é facilmente diferenciado de Limnocharis pelas folhas flutuantes na lâmina d'água, além das características de fruto e semente (veja a chave). Hydrocleys inclui cinco espécies, que ocorrem desde o sul do México até o nordeste da Argentina (Haynes \& Holm-Nielsen 1992), todas elas encontradas no Brasil, distribuídas em todos os domínios fitogeográficos, sendo apenas $H$. martii e $H$. nymphoides referidas para a Bahia (Lopes \& Sakuragui 2015a). O presente trabalho acrescenta a ocorrência de $H$. modesta na Bahia.

\section{Chave para as espécies}

1. Plantas delicadas, ca. $10 \mathrm{~cm}$ alt.; flor com 5-8 estames, sem estaminódios ........... 1.2. H. modesta

1'. Plantas robustas, 20-40 cm alt.; flor com 18-32 estames e com estaminódios.

2. Sépalas com nervura central evidente; pétalas amarelas, base alaranjada; estaminódios amarelados; carpelos 4 ou 5, estigma da mesma altura que os estames, amarelado; sementes $<1$ mm compr., densamente pubescentes

1. H. martii

2'. Sépalas sem nervura central evidente; pétalas creme, base amarelada; estaminódios vináceos; carpelos 6-8, estigma mais alto que os estames, vináceo; sementes $>1 \mathrm{~mm}$ compr., esparsamente pubescentes.... 1.3. H. nymphoides

\subsection{Hydrocleys martii Seub. in Martius, Fl. Bras. 3(1):} 116. 1847.

Figuras $1 \mathrm{~A}-\mathrm{G}$ e 2.

Ervas $20-40 \mathrm{~cm}$ alt. Folhas pecioladas; pecíolo 3$18,5 \times 0,1-0,3 \mathrm{~cm}$, verde, glabro; lâmina 2,8-8,8 × 2-7 $\mathrm{cm}$, largamente elíptica a largamente oval, verde, 7-10nervada, glabra, ápice agudo a arredondado, base cordada, lobos 3-15 $\mathrm{mm}$ compr., raramente imbricados. Inflorescência com proliferações vegetativas, 3-7-flora; escapo 8-40 × 0,1-0,3 cm, verde, glabro; brácteas 4-6, lanceoladas a ovais, ápice acuminado a obtuso. Flores com pedicelo 2,4-9 × 0,1$0,3 \mathrm{~cm}$, verde; sépalas $1,3-2,2 \times 0,5-0,7 \mathrm{~cm}$, verdes, raramente vináceas, lanceoladas a ovais, nervura central evidente, raramente proeminente, glabras; pétalas amarelas com base alaranjada; estames 18-24, filetes 3-6 mm compr., hialinos, amarelo-claros, glabros; anteras 1,9-3 mm compr., estreito-elípticas a sagitadas, amarelas; estaminódios numerosos, 6-8 mm compr., filiformes, ápice frequentemente bifurcado, hialinos, amarelados, glabros; carpelos 4 ou 5, 4-8 mm compr., amarelo-claros, glabros; estilete 1,8-4 $\mathrm{mm}$ compr., ápice ereto, raramente levemente curvado, glabro; estigma capitado, amarelado, na mesma altura que os estames. Frutos 10-15 mm compr. Sementes 0,7-1 mm compr., acastanhadas, densamente pubescentes.

Hydrocleys martii ocorre no Uruguai (Haynes \& Holm-Nielsen 1992) e nas Regiões Norte (Pará) e Nordeste do Brasil (Lopes \& Sakuragui 2015a). Na Bahia, ocorre principalmente na porção central do estado. B4, B5, E6, F6, D7, E8, G8, B9, E9: Caatinga e Cerrado.

Material selecionado - Andaraí, 12²4 $47^{\prime \prime} \mathrm{S}, 4^{\circ} 18^{\prime} 33^{\prime \prime} \mathrm{W}, 17$ dez. 2006, I. Oliveira 76 (HUEFS); Anguera, $12^{\circ} 11^{\prime} \mathrm{S}, 39^{\circ} 09^{\prime} \mathrm{W}, 6$ out. 1996, F. França \& E. Melo 1899 (CEPEC, HUEFS); Bendengó, 09 57'30"S, 39¹1'19"W, 23 fev. 2000, A.M. Giulietti et 
al. 1767 (HUEFS); Cabeceiras do Paraguaçu, 7 ago. 2012, L.Y.S Aona et al. 1588 (HURB); Cachoeira, Riacho Cungu, 12³1'48"S, 3949'48"W, nov. 1980, Grupo Pedra do Cavalo 947 (ALCB, CEPEC, HRB); Campo Alegre de Lourdes, 09² $28^{\prime} 53^{\prime \prime} \mathrm{S}$, $43^{\circ} 05^{\prime} 05^{\prime \prime W}, 14$ jun. 2001, T.S. Nunes et al. 402 (ALCB, CEPEC,

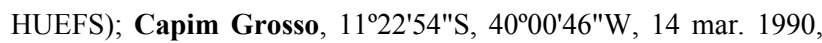
A.M. Carvalho et al. 2773 (HUEFS); Contendas do Sincorá, 134ㄴ'44"S, 41'2'33"W, 11 jan. 2000, A.M. Giulietti et al. 1702 (HUEFS); Coração de Maria, 22 set. 1995, F. França et al. 1360 (HUEFS); Cruz das Almas, 29 set. 2010, L.Y.S. Aona et al. 1364 (HURB); Euclides da Cunha, 10'28'36"S, 3901'00"W, $21 \mathrm{fev.}$ 2000, A.M. Giulietti 1718 (HUEFS); Feira de Santana, 8 jul. 1982, M.L. Guedes 525 (ALCB); Iaçu, Lagedo Alto, fazenda Lapa, abr. 1974, A.L. Costa 344 (ALCB, HRB, HUEFS); Ipirá, fazenda Caldeirão, 4 out. 1984, B.C. Bastos 483 (ALCB, CEPEC, HRB); Itaberaba, 4 jun. 1995, F. França et al. 1213 (HUEFS); Jacobina, Barracão de Cima, $11^{\circ} 01^{\prime} 07^{\prime \prime S}, 40^{\circ} 32^{\prime} 43^{\prime \prime} \mathrm{W}, 6$ jul. 1996, H.P. Bautista PCD 3461 (ALCB, K); Jaguarari, 10¹0'32"S, 40¹3'39"W, 28 jul. 2005, D.S. Carneiro-Torres et al. 371 (HUEFS); Jequié, 13⒌'S, 4005'W, 9 fev. 1969, A. Gentry 49999

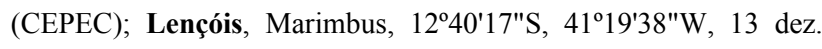
2002, F. França et al. 3896 (ALCB, HRB, HUEFS); Livramento de Nossa Senhora, encontro do Rio do Paulo com o rio Brumado, 16 maio 1991, A.J. Ribeiro 286 (ALCB); Manoel Vitorino, 16 fev. 1978, L.A. Mattos Silva et al. 300 (CEPEC, K, NY); Maracás, 26 abr. 1974, S.A. Mori et al. 9966 (CEPEC, K, NY); Muritiba, mineradora nos arredores do aterro sanitário, 12 $38^{\prime} 24^{\prime \prime} \mathrm{S}, 39^{\circ} 00^{\prime} 45^{\prime \prime} \mathrm{W}, 4$ maio 2000, F. França et al. 3332 (ALCB, HRB, HUEFS); Paulo Afonso, 7 jun. 1981, S.A. Mori \& B.M. Boom 14242 (CEPEC, K, NY); Pilão Arcado, 0953'34"S, 42³3'59"W, 29 fev. 2000, M.L. Guedes 7012 (HRB, NY); Ribeira do Pombal, 1050'S, 38³3'W, 1 mar. 1984, L.R. Noblick 2957 (HUEFS); Sapeaçu, 5 out. 2010, L.Y.S. Aona et al. 1386 (HURB); Senhor do Bonfim, 10²2'47"S, 4009'23"W, 29 jul. 2005, P.D. Carvalho et al. 209 (HUEFS); Vitória da Conquista, 15 fev. 1974, T.S. Santos 2250 (CEPEC).

Hydrocleys martii apresenta como característica marcante as sépalas com a nervura central bem evidente. A espécie também pode ser diferenciada das demais da Bahia por suas pétalas amarelas com base alaranjada e os estames, frequentemente, com o comprimento superior ou igual ao dos carpelos.

Assim como descrito para espécimes de Hydrocleys martii do Ceará (Matias \& Sousa 2011), muitos indivíduos coletados e analisados na Bahia, apresentam 18 a 24 estames, portanto, geralmente mais que os 12 a 18 referidos para a espécie por Haynes \& HolmNielsen (1992). Situação semelhante ocorre em relação ao número de carpelos, que nos espécimes da Bahia varia entre 4 e 5, sendo 4 o número mais comum, enquanto Haynes \& Holm-Nielsen (1992) referem entre 5 e 8 carpelos para a espécie.

1.2. Hydrocleys modesta Pedersen, Bot. Tidskr. 57: 39. 1961.

Figuras $1 \mathrm{H}-\mathrm{L}$ e 2.

Ervas ca. $10 \mathrm{~cm}$ alt. Folhas pecioladas; pecíolo 11 $25 \times$ ca. $0,1 \mathrm{~cm}$, verde, glabro; lâmina 2,5-3,8 $\times 1,8$ $2,5 \mathrm{~cm}$, largamente elíptica a oval, verde, 5-nervada, glabra, ápice arredondado, base arredondada, raramente subcordada, lobos ca. $3 \mathrm{~mm}$ compr., não imbricados. Inflorescência sem proliferações vegetativas, 2-5-flora; escapo 9-10 × ca. 0,1 cm, verde, glabro; brácteas 2-5, oblongas, ápice obtuso. Flores com pedicelo 3,5-6 × ca. 0,1 cm, verde; sépalas ca. $0,9 \times 0,4 \mathrm{~cm}$, verde, ovais a lanceoladas, nervura central não evidente, glabras; pétalas amarelas; estames ca. 5, filetes 4-5 mm compr., hialinos, glabros; anteras elípticas, 1-1,3 mm compr., amarelas; estaminódios ausentes; carpelos 3 ou 4, ca. $5 \mathrm{~mm}$ compr., amareloclaros, glabros; estilete ca. 2,5 mm compr., ápice curvado, glabro; estigma capitado, amarelado, na mesma altura que os estames. Frutos 5-7 mm compr. Sementes ca. $0,7 \mathrm{~mm}$ compr., castanho-claras, densamente pubescentes.

A espécie ocorre do Brasil (Regiões Nordeste, Centro-Oeste e Sudeste) ao sudoeste da Argentina, em pequenos lagos e rios de águas calmas, em altitudes que variam de 0-500 m (Haynes \& Holm-Nielsen 1992; Lopes \& Sakuragui 2015a). Esse é o primeiro registro da espécie para a Bahia, encontrada apenas em uma localidade no sudoeste do estado. F8: Caatinga.

Material examinado - Bom Jesus da Lapa, 13⒉ $14^{\prime \prime}$, $43^{\circ} 21^{\prime} 43^{\prime \prime W}, 11$ fev. 2000, L.P. Queiroz et al. 5891 (CEPEC, HUEFS).

Hydrocleys modesta é facilmente distinta das demais espécies congenéricas ocorrentes na Bahia pelo seu porte menor, com folhas e flores pequenas. Também pode ser reconhecida pela ausência de estaminódios e menor número de estames.

\subsection{Hydrocleys nymphoides (Humb. \& Bonpl. ex} Willd.) Buchenau, Abh. Naturw. Ver. Bremen 2: 2. 1871.

Figuras $1 \mathrm{M}-\mathrm{R}$ e 2.

Ervas 20-40 cm alt. Folhas pecioladas; pecíolo 6$16 \times 0,2-0,4 \mathrm{~cm}$, verde, glabro; lâmina 4,5-8,5 × 4,5$7,8 \mathrm{~cm}$, largamente oval a arredondada, verde, 7-9nervada, glabra, ápice obtuso a arredondado, base cordada, lobos 3-5 mm compr., imbricados ou não. Inflorescência com proliferações vegetativas, 2-4flora; escapo ca. $20 \times 0,3 \mathrm{~cm}$, verde, glabro; brácteas ca. 4, lanceoladas a estreito-ovais, ápice acuminado a agudo. Flores com pedicelo 4-19 × 0,1-0,4 cm, verde; sépalas $1,5-2,4 \times 0,8-1,1 \mathrm{~cm}$, verdes, largamente elípticas a ovais, nervura central não evidente, glabras; pétalas creme, com base amarelada; estames 24-32, filetes 1,8-3,5 $\mathrm{mm}$ compr., hialinos, glabros; anteras 4-6 mm compr., elípticas a sagitadas, vináceas, raramente amareladas; estaminódios numerosos, 4-5 mm compr., filiformes, ápice frequentemente bifurcado, hialinos, vináceos, glabros; carpelos 6-8, 9$13 \mathrm{~mm}$ compr., vináceos, glabros; estilete 4-6 mm compr., ápice ereto ou levemente curvado, glabro; estigma capitado, vináceo, mais alto que os estames. Frutos 16-18 mm compr. Sementes ca. 1,1 $\mathrm{mm}$ compr., castanho-claras, esparso-pubescentes. 

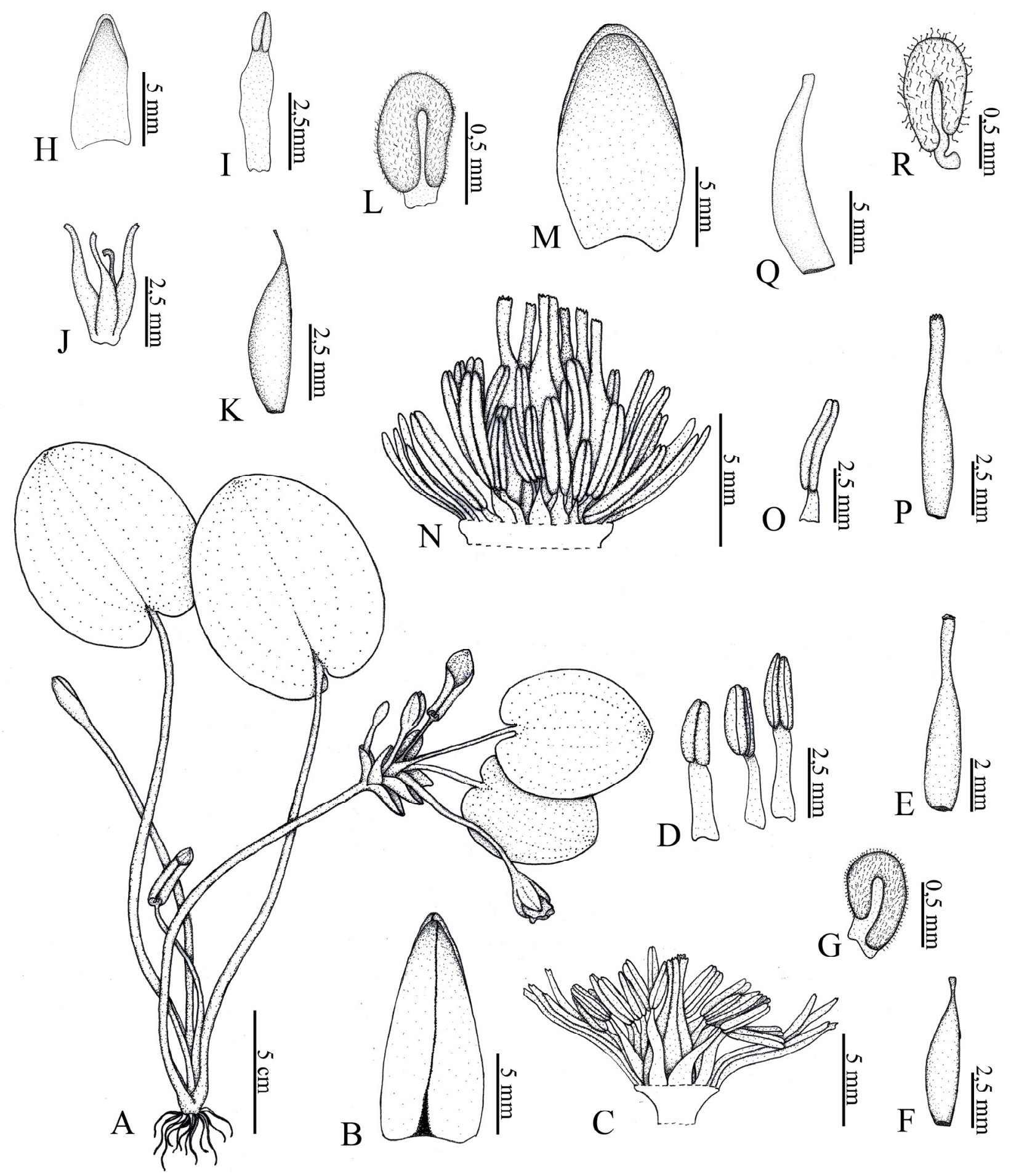

Figura 1. A-G. Hydrocleys martii: A- hábito; B- sépala com nervura central evidente; C- detalhe da flor com cálice e corola removidos, evidenciando o androceu e o gineceu; D- estames; E- carpelo; F- fruto; G- semente. H-L. H. modesta: H- sépala. I- estame; J- carpelos; Kfruto; L- semente. M-R. H. nymphoides: M- sépala; N- detalhe da flor, com cálice e corola removidos, evidenciando o androceu e o gineceu; O- estame; P- carpelo; Q- fruto; R- semente (A- França et al. 3332; B, C- França et al. 1360; D-G- França et al 3896; H-LQueiroz 5891; M-R- França 5006).

Hydrocleys nymphoides é uma espécie de distribuição neotropical, ocorrendo no sul dos Estados Unidos, América Central (Guatemala), Caribe (Porto Rico) e na América do Sul, até o norte da Argentina (Haynes \& Holm-Nielsen 1992). De acordo com Pansarin
\& Amaral (2002) e Lopes \& Sakuragui (2015a), é amplamente distribuída no Brasil, referida para todos os domínios fitogeográficos. Na Bahia, ocorre de forma dispersa na região central e litoral do estado. D7, D9, E9, H9: Caatinga e Mata Atlântica. 
Material examinado - Candeias, $12^{\circ} 38^{\prime} 43^{\prime \prime} \mathrm{W}, 38^{\circ} 28^{\prime} 38^{\prime \prime} \mathrm{S}, 24$ jun. 2004, F. França \& E. Melo 5006 (HUEFS); Belmonte, 17 abr. 1975, T.S. Santos 2985 (CEPEC); Jacobina, margem do rio

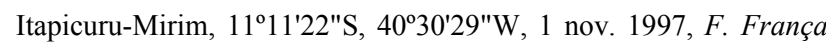
et al. 2454 (HUEFS); Mata de São João, 12 $2^{\circ} 31^{\prime} \mathrm{S}, 38^{\circ} 17^{\prime} \mathrm{W}, 23$ mar. 2000, D.L. Santana 91 (ALCB); São Felipe, 26 mar. 2013, L.Y.S. Aona et al. 2542 (HURB); Santa Bárbara, fazenda Pojuca, $11^{\circ} 55^{\prime} 53^{\prime \prime} \mathrm{W}, 38^{\circ} 58^{\prime} 44^{\prime \prime} \mathrm{S}, 26$ nov. 2005, E. Melo et al. 4216 (HUEFS).

Em relação às demais espécies desse gênero ocorrentes na Bahia, Hydrocleis nymphoides pode ser distinta pelas folhas mais robustas e número maior de estames e carpelos. Distingue-se de $H$. martii, a espécie mais similar, pelos estames com filetes mais curtos que as anteras e menores que os carpelos, com estigmas posicionados acima das anteras e com coloração vinácea (H. martii possui estigmas amarelados posicionados na mesma altura das anteras).

\section{Limnocharis Humb. \& Bonpl.}

Ervas emergentes, estolões raramente presentes. Folhas emersas; pecíolos inflados, triangulares; lâminas lanceoladas a ovais, ápice agudo a obtuso, levemente emarginado-mucronado, base cuneada a arredondada. Inflorescências raramente com proliferações vegetativas, com poucas a várias flores; escapo ereto, não septado; brácteas elípticas a ovais. Flores com pedicelo triangular, inflado, frequentemente alado; sépalas verdes, largamente ovais, ápice não cuculado, nervura central não evidente; pétalas amarelas, obovais; estames 15 a vários, filetes lineares, anteras oblongas a lanceoladas; estaminódios numerosos, em 1 a várias séries, ápice

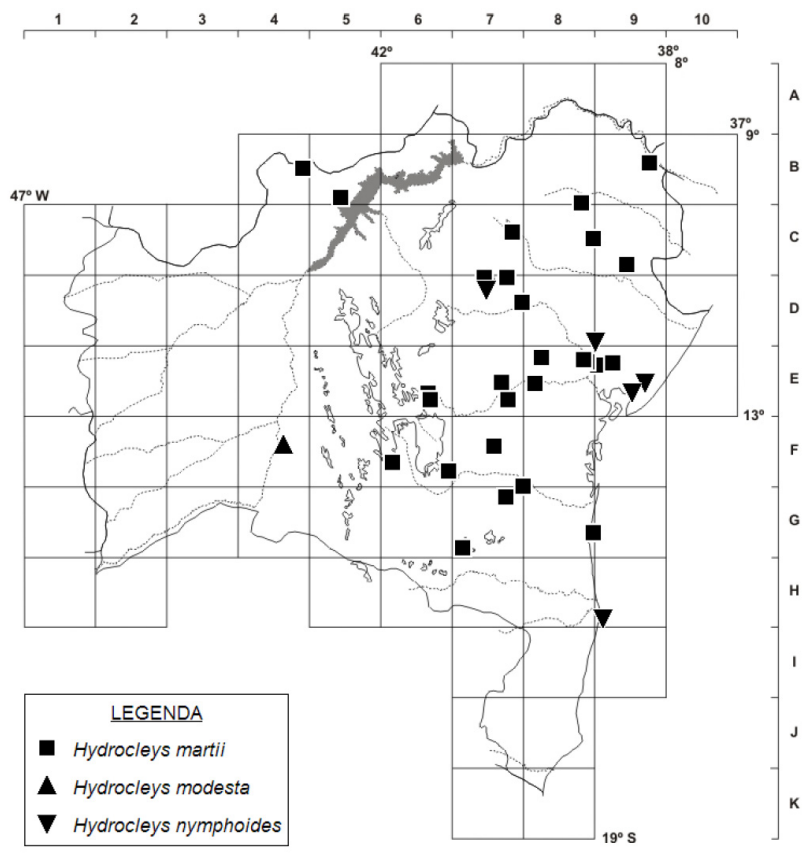

Figura 2. Mapa de distribuição de Hydrocleys martii, $H$. modesta e H. nymphoides no estado da Bahia. bifurcado ou arredondado; gineceu 14-19-carpelar, carpelos achatados lateralmente, estilete ausente. Frutos semicirculares, achatados lateralmente. Sementes com costelas transversais, glabras.

Limnocharis é um gênero neotropical e inclui apenas duas espécies, L flava (L.) Buchenau e $L$. laforestii Duchass. ex Griseb., que se distribuem do México e Caribe até a Argentina, estando naturalizadas em algumas regiões do sudeste Asiático (Haynes \& Holm-Nielsen 1992). Ambas as espécies ocorrem em várias localidades do Brasil (Lopes \& Sakuragui 2015b).

\section{Chave para as espécies}

1. Plantas robustas, $30-70 \mathrm{~cm}$ alt.; folhas largamente elípticas a largamente ovais; escapo da inflorescência maior que os pecíolos; pedicelos inflados; estaminódios 50-80, ápice bifurcado

2.1 L. flava

1'. Plantas delicadas, 20-40 cm alt.; folhas lanceoladas; escapo da inflorescência menor que os pecíolos; pedicelos frequentemente não inflados, quando inflados apenas na porção apical; estaminódios ca. 15, ápice arredondado

2.2 L. laforestii

2.1. Limnocharis flava (L.) Buchenau, Abh. Nat. Ver. Bremen 2: 2. 1868.

Figuras 3 e $4 \mathrm{~A}-\mathrm{E}$.

Ervas $30-70 \mathrm{~cm}$ alt. Folhas com pecíolo $15-54 \times$ 0,4-0,6 cm, verde, glabro; lâmina 10-30 × 6-14 cm, largamente elíptica a oval, verde, 9-14-nervada, glabra, ápice arredondado a levemente retuso, mucronado, base arredondada, raramente levemente cordada. Inflorescência geralmente com proliferações vegetativas, 5-14-flora; escapo inflado, 12-55 × 0,6-2 $\mathrm{cm}$, verde, alado, glabro; brácteas 5-14, oblongas, ápice arredondado. Flores com pedicelo $2-4 \times 0,15-$ $0,8 \mathrm{~cm}$, triangular, com alas bem desenvolvidas, verde, inflado; sépalas 1,5-2 cm compr., verdes, côncavas, glabras; pétalas creme com base amarelada; estames ca. 30, filetes 2-3 mm compr., hialinos, glabros; anteras 2,3-4 $\mathrm{mm}$ compr., sagitadas a elípticas, amarelas; estaminódios 50-80, ca. $10 \mathrm{~mm}$ compr., filiformes, ápice bifurcado, hialinos, glabros; carpelos 15-19, ca. $8 \mathrm{~mm}$ compr., amarelo-claros, glabros; estigma séssil, não espiralado. Frutos 13-16 × 4-5 mm. Sementes 1-1,4 mm compr., marrons, 13-15 costadas.

Espécie neotropical que ocorre do norte do México até o Brasil, em altitudes de até $1.500 \mathrm{~m}$ (Haynes \& Holm-Nielsen 1992). Possui registros para todo o território nacional (Lopes \& Sakuragui 2015b). Na Bahia, ocorre no litoral sul. G8: Mata Atlântica.

Material examinado - Ilhéus, rodovia Uruçuca-Ilhéus, plantação de cacau, 2 jun. 1971, R.S. Pinheiro 1254 (CEPEC); Itacaré, 14¹7'S, $38^{\circ} 59^{\prime} \mathrm{W}, 31$ jan. 1977, R.M. Harley 18454 (CEPEC, K, NY). Uruçuca, EMARC, 20 abr. 1970, T.S. Santos 755 (CEPEC). 
Material adicional examinado - Ceará, Fortaleza, açude Santo Anastácio, Campus do Pici-UFC, 18 maio 2011, D.J.L. Sousa. 136 (EAC); São Gonçalo do Amarante, Lagamar do Cauípe, 8 fev. 2012, L.Q. Matias 621 (EAC).

Limnocharis flava pode ser encontrada em diversos tipos de ambientes dulcícolas, sendo estes, na grande maioria, lênticos e ricos em matéria orgânica. Desta forma, não é incomum encontrar populações da espécie se desenvolvendo em ambientes eutrofizados ou poluídos. Os indivíduos apresentam folhas largamente elípticas a ovais e são mais robustos do que aqueles de L. laforestii. Outra característica marcante é a presença de flores com pedicelo trígono e inflado, possuindo alas longitudinais bem desenvolvidas. Apesar desses caracteres diferenciais, a distinção entre as duas espécies é problemática. Os caracteres diagnósticos frequentemente utilizados (formato das folhas e tamanho do escapo em comparação com os pecíolos) podem ser influenciados por fatores físico-químicos da água, como descrito por Sculthorpe (1967) para outros grupos de plantas aquáticas. Desta forma, é ainda questionável o reconhecimento de L. laforestii como um táxon distinto de L. flava.

\subsection{Limnocharis laforestii Duchass. ex Griseb.,} Bonplandia 6: 11. 1858.

Figuras 3 e $4 \mathrm{~F}-\mathrm{L}$.

Ervas $20-40 \mathrm{~cm}$ alt. Folhas com pecíolo $10-18 \times$ 0,3-0,4 cm, verde, glabro; lâmina 8-13,5 × 3-4 cm, lanceolada a elíptica, verde, 7-11-nervada, glabra, ápice obtuso a acuminado, mucronado, base cuneada a arredondada. Inflorescência sem proliferações vegetativas, 5-7-flora; escapo não inflado, 7-14 $\times$ 0,3-0,8 cm, verde, não alado, glabro; brácteas 5-7, oblongas, ápice arredondado. Flores com pedicelo $2-4 \times 0,15-0,4 \mathrm{~cm}$, não alado, verde, frequentemente não inflado, quando inflado apenas na porção apical; sépalas 1,3-1,6 cm compr., verdes, côncavas, glabras; pétalas creme com base amareloclara; estames ca. 20, filetes 1,9-2,3 mm compr., hialinos, glabros; anteras sagitadas a elípticas, 1,3-2 mm compr., amarelas; estaminódios ca. 15, ca. $9 \mathrm{~mm}$ compr., filiformes, ápice arredondado, hialinos, glabros; carpelos 14-16, ca. $5 \mathrm{~mm}$ compr., amareloclaros, glabros; estigma séssil, levemente espiralado. Frutos $10-12 \times 3-4 \mathrm{~mm}$. Sementes 0,7-0,9 $\mathrm{mm}$ compr., castanho-escuras, 13-15-costadas.

Limnocharis laforestii ocorre do México à Argentina (Haynes \& Holm-Nielsen 1992). No Brasil, possui distribuição conhecida em estados da Região Norte (Pará, Amapá, Acre), Centro-Oeste (Mato Grosso e Mato Grosso do Sul), Sudeste (São Paulo) e Nordeste (Maranhão, Piauí, Ceará, Paraíba, Pernambuco e Bahia) (Pansarin \& Amaral 2012; Lopes \& Sakuragui 2015b). Na Bahia, ocorre na porção oeste do Estado. D2, F4: Cerrado.

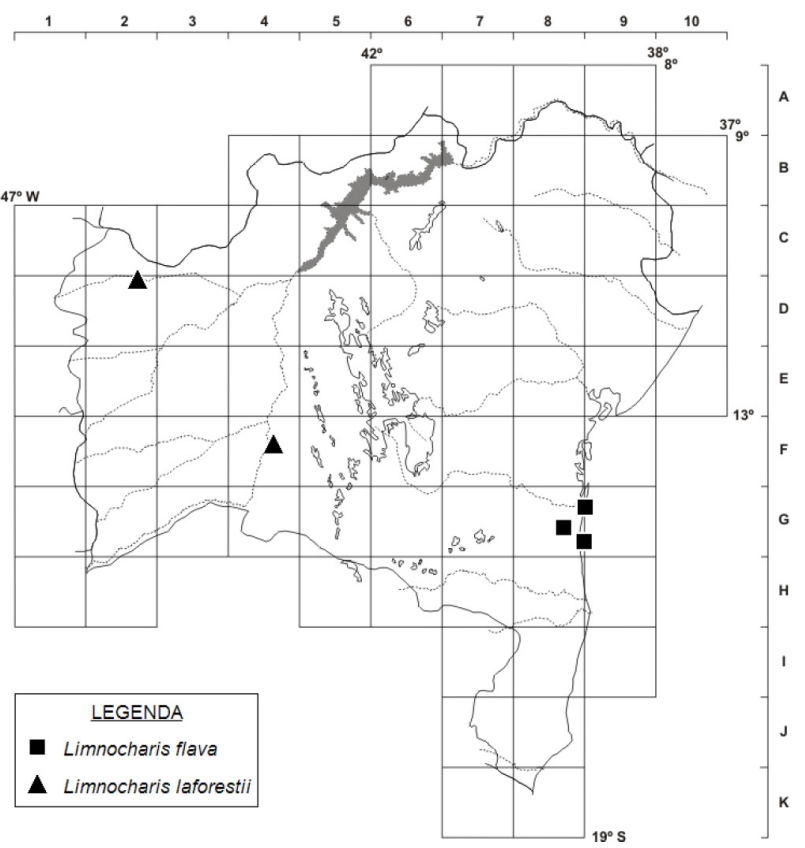

Figura 3. Mapa de distribuição de Limnocharis flava e L. laforestii no estado da Bahia.

Material examinado - Bom Jesus da Lapa, 13⒉ $14^{\prime \prime}$ "S, $43^{\circ} 21^{\prime} 43^{\prime \prime} \mathrm{W}, 11$ fev. 2000, L.P. Queiroz et al. 5884 (HUEFS); Formosa do Rio Preto, brejo próximo ao rio Preto, $11^{\circ} 03^{\prime} 34^{\prime \prime S}$, $45^{\circ} 16^{\prime} 17^{\prime \prime W}, 30$ mar. 2000, E.B. Miranda et al., 380 (HRB, HUEFS)

Material adicional examinado - Ceará, Iguatu, CE060, 10 jul. 2010, L.R.O. Normando 500 (EAC).

A espécie é distinta de L. flava por possuir escapos mais curtos que os pecíolos, pedicelos levemente inflados no ápice e folhas mais estreitas, lanceoladas a elípticas. O material da Bahia (Miranda 380) possui mais estames (10-15) que o número descrito para a espécie por Haynes \& Holm-Nielsen (1992), sendo aqui tratados como L. laforestii com base nas características diagnósticas já citadas.

\section{Agradecimentos}

Aos curadores dos herbários ALCB, CEPEC, HRB, HUEFS, K e NY pelo acesso às coleções e bibliotecas. À equipe do REFLORA em Kew e NYBG, por todo o suporte logístico, especialmente à Catia Canteiro e Carla de Lima pelo repatriamento dos materiais em Kew e Paris. À FAPESB, pelo auxílio financeiro ao projeto Flora da Bahia (processo APR0162/2007). Ao CNPq, pelo apoio financeiro aos projetos Flora da Bahia (processos 562278/2010-9 e 483909/2012) e REFLORA (processo 563558/20105), incluindo auxílio na realização de visitas aos herbários, expedições de campo e bolsas de estudo concedidas aos autores (DJLS, mestrado; AMG, PQ Sênior; e RPO, PQ1D). 


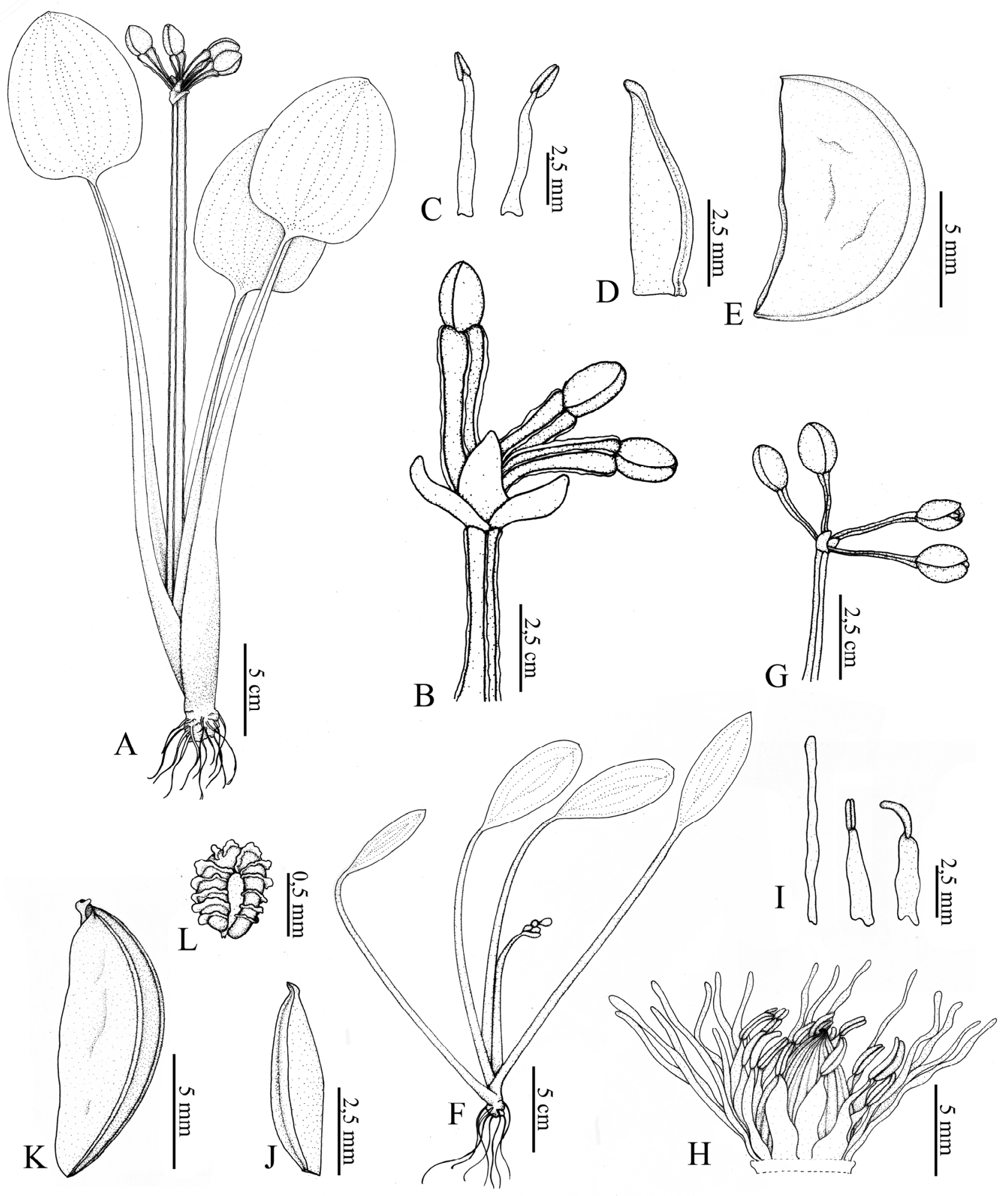

Figura 4. A-E. Limnocharis flava: A- hábito; B- inflorescência; C- estames; D- carpelo; E- fruto. F-L. L. laforestii: F- hábito; Ginflorescência; H- detalhe da flor com cálice e corola removidos; I- estaminódio e estames; J- carpelo; K- fruto; L- semente (A- Pinheiro 1254; B-E- Sousa 136; F- Normando 500; G-L- Queiroz 5884).

\section{REFERÊNCIAS}

APG II. 2003. An update of the Angiosperm Phylogeny Group classification for the orders and families of flowering plants: APG II. Botanical Journal of the Linnean Society 141: 399436.
APG III. 2009. An update of the Angiosperm Phylogeny Group classification for the orders and families of flowering plants: APG III. Botanical Journal of the Linnean Society 161: 105121.

Chen, J.-M.; Chen, D.; Gituru, W.R.; Wang, Q.F. \& Guo, Y.H. 2004. Evolution of apocarpy in Alismatidae using phylogenetic 
evidence from chloroplast $r b c L$ gene sequence data. Botanical Bulletin of Academia Sinica 45: 33-40.

Cronquist, A. 1981. An Integrated System of Classification of Flowering Plants. Columbia University Press, New York.

Cuenca, A.; Petersen, G.; Seberg, O.; Davis, J.I. \& Stevenson, D.W. 2010. Are substitution rates and RNA editing correlated? $B M C$ Evolutionary Biology 10: 349-364.

Cuenca, A.; Petersen, G.; Seberg, O. \& Jahren, A.H. 2012. Genes and processed paralogs co-exist in plant mitochondria. Journal of Molecular Evolution 74: 158-169.

Furness, C.A. \& Banks, H. 2010. Pollen evolution in the earlydivergent monocot order Alismatales. International Journal of Plant Sciences 171(7): 713-739.

Haynes, R.R. \& Holm-Nielsen, L.B. 1992. The Limnocharitaceae. Flora Neotropica 56: 1-32.

Heywood, V.H.; Brummit, R.K.; Culham, A. \& Seberg, O. 2007. Flowering Plant Families of the World. Firefly Books, Ontario.

Lehtonen, S. 2009. Systematics of the Alismataceae - a morphological evaluation. Aquatic Botany 91: 279-290.

Lehtonen, S. \& Myllys, L. 2008. Cladistic analysis of Echinodorus (Alismatacaea): simultaneous analysis of molecular and morphological data. Cladistics 24: 218-239.

Les, D.H.; Cleland, M.A. \& Waycott, M. 1997. Phylogenetic studies in Alismatidae, II: evolution of marine angiosperms (seagrasses) and hydrophily. Systematic Botany 22: 443-463.

Li, X. \& Zhou, Z. 2009. Phylogenetic studies of the core Alismatales inferred from morphology and $r b c \mathrm{~L}$ sequences. Progress in Natural Science 19: 931-945.

Lopes, R.C. \& Sakuragui, C.M. 2015a. Hydrocleys. In: Lista de Espécies da Flora do Brasil. Instituto de Pesquisas Jardim Botânico do Rio de Janeiro. Disponível em http://floradobrasil.jbrj.gov.br/ jabot/floradobrasil/FB102842; acesso em maio 2015.

Lopes, R.C. \& Sakuragui, C.M. 2015b. Limnocharis. In: Lista de Espécies da Flora do Brasil. Instituto de Pesquisas Jardim Botânico do Rio de Janeiro. Disponível em http://floradobrasil.jbrj.gov.br/ jabot/floradobrasil/FB8609; acesso em maio 2015.

Matias, L.Q. \& Sousa, D.J.L. 2011. Alismataceae no estado do Ceará, Brasil. Rodriguésia 62(4): 887-900.

Matias, L.Q.; Sakuragui, C.M. \& Lopes, R.C. 2015. Alismataceae. In: Lista de Espécies da Flora do Brasil. Instituto de Pesquisas Jardim Botânico do Rio de Janeiro. Disponível em http:// floradobrasil.jbrj.gov.br/2012/FB004257; acesso em maio 2015.

Pansarin, E.R. 2015. Neotropical Limnocharitaceae. Disponível em http://www.kew.org/science/tropamerica/neotropikey/families/Limn ocharitaceae.htm; acesso em maio 2015.

Pansarin, E.R. \& Amaral, M.C.E. 2002. Limnocharitaceae. In: M.G.L. Wanderley, G.J. Shepherd \& A.M. Giulietti (eds), Flora Fanerogâmica do Estado de São Paulo. Vol. 2. Hucitec, São Paulo, p. $155-157$.

Petersen, G.; Seberg, O.; Davis, J.I. \& Stevenson, D.W. 2006. RNA editing and phylogenetic reconstruction in two monocot mitochondrial genes. Taxon 55: 871-886.

Petersen, G.; Seberg, O.; Cuenca, A.; Stevenson, D.W.; Thadeo, M.; Davis, J.I.; Graham, S. \& Ross, T.G. 2015. Phylogeny of the Alismatales (Monocotyledons) and the relationship of Acorus (Acorales?). Cladistics 1-19.

Sakuragui, C. M; Matias, L.Q. \& Lopes, R.C. 2010. Limnocharitaceae. In: Lista de Espécies da Flora do Brasil. Vol. 2. Jardim Botânico do Rio de Janeiro, Rio de Janeiro, p. 1166. Disponível em http://reflora.jbrj.gov.br/downloads/vol2.pdf; acesso em maio 2015.

Sculthorpe, C.D. 1967. The Biology of Aquatic Vascular Plants. St. Martins Press, New York.

Takhtajan, A.L. 1954. Proiskhozhdenie pokrytosemennykh rastenii. Moskva. - Engl. transl. 0.H. Gankin. 1958. Origin of Angiospermous plants. American Institute of Biology Sciences, Washington.

\section{LISTA DE EXSICATAS}

Aona, L.Y.S. 1045, 1131, 1364, 1386, 1588 (1.1), 2542 (1.3); Bautista, H.P. PCD 3461 (1.1); Carneiro-Torres, D.S. 371 (1.1); Carvalho, A.M. 2773 (1.1); Carvalho, P.D. 209 (1.1); Costa, A.L. s.n. ALCB 344 (1.1); Bastos, B.C. 481, 483 (1.1); Berg, C. 928 (1.1); Brito, K.B. 38 (1.1); Eiten, G. 4993 (1.1); França, F. 1213, 1360, 1899, 2235 (1.1), 2454 (1.3), 3322, 3896 (1.1), 5006 (1.3); Forzza, R.C. 1308 (1.1); Gentry, A. 49999 (1.1); Giulietti, A.M. 1702, 1718, 1767 (1.1); Grupo Pedra do Cavalo 947 (1.1); Guedes, M.L. 525, 7012, PCD 4618 (1.1); Harley, R.M. 18454 (2.1), 21439 (1.2), PCD 5490 (1.1); Leite, K.R.B. 297 (1.1); Mattos-Silva, L.A. 300 (1.1); Melo, E. 2068,2203 (1.1), 4216 (1.3); Miranda, E.B. 380 (2.2), 606 (1.1); Mori, S.A. 9966, 14242 (1.1); Noblick, L.R. 2957, 3649 (1.1); Normando, L.R.O. 500 (2.2); Nunes, T.S. 402 (1.1); Oliveira, I. 76. (1.1); Pinheiro, R.S. 1254 (2.1); Queiroz, L.P. 5884 (2.2), 5891 (1.2); Ribeiro, A.J. 286 (1.1); Santana, D.L. 91 (1.3); Santos, T.S. 755 (2.1), 2250 (1.1), 2985 (1.3); Sousa, D.J.L. 136 (2.1); Souza, E.R. 219 (1.1). 